\title{
FACTORS PREDICTING RESPONSE TO NEOADJUVANT CHEMOTHERAPY IN LOCALLY ADVANCED GASTRIC CANCER
}

\author{
LOKAL ILERI MIDE KANSERINDE NEOADJUVAN KEMOTERAPIYE YANITI ÖNGÖREN \\ FAKTÖRLER
}

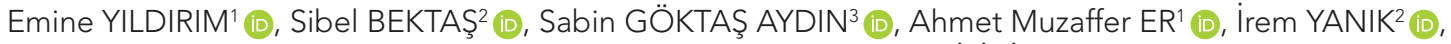 \\ Perihan Özkan GÜMÜŞKAYA ${ }^{4}$ (D), Barbaros Utku YILMAZ ${ }^{1}$ (D), Ahmet BiLiCi ${ }^{3}$ (D), Mustafa ÖNCEL ${ }^{5}$ (D) \\ 'University of Health Sciences, Gaziosmanpasa Training and Research Hospital, Department of General Surgery, Istanbul, Turkey \\ ${ }^{2}$ University of Health Sciences, Gaziosmanpasa Training and Research Hospital, Department of Pathology, Istanbul, Turkey \\ ${ }^{3}$ Medipol University, Faculty of Medicine, Department of Medical Oncology, Istanbul, Turkey \\ ${ }^{4}$ University of Health Sciences, Prof. Dr. Cemil Tascioglu City Hospital, Department of Internal Medicine, Istanbul, Turkey \\ ${ }^{5}$ Medipol University, Faculty of Medicine, Department of General Surgery, Istanbul, Turkey
}

ORCID IDs of the authors: E.Y. 0000-0003-2733-402X; S.B. 0000-0003-0248-9869; S.G.A. 0000-0002-0077-6971;

A.M.E. 0000-0001-8578-1229; I.Y. 0000-0001-6227-1189; P.Ö.G. 0000-0002-0838-9220; B.U.Y. 0000-0003-3352-4823;

A.B. 0000-0002-0443-6966; M.Ö. 0000-0003-2357-5387

Cite this article as: Yildirim E, Bektas S, Goktas Aydin S, Er AM, Yanik I, Gumuskaya PO, et al. Factors Predicting Response to neoadjuvant chemotherapy in locally advanced gastric cancer. J Ist Faculty Med 2022;85(1):41-50. doi: 10.26650/IUITFD.950751

\section{ABSTRACT}

Objective: In the treatment of local advanced gastric cancer (LAGC), it is recommended to start with neoadjuvant chemotherapy (NAC). Although the benefits of NAC have been shown, it is still not fully understood which patients respond better. The aim of this study was to investigate the effect of hematological and histopathological parameters on the response to chemotherapy.

Materials and Methods: A retrospective examination was made of 38 patients who underwent surgery for LAGC after receiving NAC. Evaluations were made by comparing the demographic characteristics, histopathological characteristics in an endoscopic biopsy of the tumor, preoperative hemoglobin levels, and neutrophil-lymphocyte ratios with the postoperative pathological response to determine which tumor characteristics gave a better response.

Results: In the postoperative histopathological evaluation, there was a pathological complete response to chemotherapy in two patients (6\%), grade 1 in 9 patients (24\%), grade 2 in 13 patients (34\%), and grade 3 in 14 patients (36\%). A statistically significant relationship was determined between the histopathological absence of perineural invasion and pathological complete response $(p=0.023)$.

Conclusion: A relationship between perineural invasion and poor response to chemotherapy was determined. Although not

\section{ÖZET}

Amaç: Lokal ileri mide kanserinde (LiMK) tedaviye neoadjuvan kemoterapi (NAK) ile başlanması önerilir. Ancak NAK'nin faydaları gösterilmiş olsa da hangi hasta gurubunun tedaviye daha iyi yanıt verdiği tam olarak anlaşılamamıştır. Çalışmamızda hematolojik ve histopatolojik parametrelerin kemoterapi yanıtı üzerine etkisi araştırılmıştır.

Yöntem ve Gereç: Bu çalışmada lokal ileri evre mide kanseri nedeni ile neoadjuvan kemoterapi görüp sonrasında ameliyat edilen 38 hasta retrospektif olarak incelendi. Ameliyat sonrası patolojik yanıt ile hastanın demografik özellikleri, tümörün endoskopik biyopsideki histopatolojik özellikleri, preoperatif hemoglobin seviyesi, nötrofil lenfosit oranı karşılaştırılıp hangi özellikteki tümörlerin daha iyi yanıt verdiği değerlendirildi.

Bulgular: Ameliyat sonrası yapılan histopatolojik değerlendirmede 2 (\%6) hastada patolojik tam yanıt, 9 (\%24) hastada grade 1 yanıt, 13 (\%34) hastada grade 2 yanıt ve 14 hastada (\%36) grade 3 yanıt mevcuttu. Patolojik tam yanıt ile histopatolojik olarak perinöral invazyon olmaması istatistiksel olarak anlamlı ilişki gösterdi $(p=0,023)$.

Sonuç: Çalışmamızda NAK alan LiMK'li hastalarda perinöral invazyon varlığının kemoterapiye kötü yanıt ile ilişkisi olduğu görülmüştür. Ayrıca lenfovaskular invazyon ve düşük grade mevcudiyetinde istatistiksel olarak anlamlı olmasa da kemoterapiye kötü yanıt gözlenmiştir.

Corresponding author/Iletişim kurulacak yazar: opdreyildirim@gmail.com

Submitted/Başvuru: 11.06.2021 • Accepted/Kabul: 04.08.2021 • Published Online/Online Yayın: 04.01.2022 
at a statistically significant level, there was also observed to be a poor response to chemotherapy in the presence of low grade and lymphovascular invasion.

Keywords: Local advanced gastric cancer, neoadjuvant chemotherapy response, pathological complete response, perineural invasion
Anahtar Kelimeler: Lokal ileri mide kanseri, neoadjuvan kemoterapi yanıtı, patolojik tam yanıt, perinöral invazyon

\section{INTRODUCTION}

Gastric cancer is the fifth most commonly diagnosed cancer worldwide, and the third most common cause of cancer-related death (1). Although 5-year survival is $>90 \%$ when determined at the early stage, approximately twothirds of patients are diagnosed at an advanced stage and survival decreases to $<50 \%$ for these patients (2-4).

The chance of a cure with surgery is high in early-stage gastric cancer, but it is recommended to start treatment of local advanced gastric cancer (LAGC) with neoadjuvant chemotherapy (NAC). According to the National Comprehensive Cancer Network (NCCN) guidelines, NAC or neoadjuvant chemoradiotherapy is recommended for LAGC patients in any group at clinical grade $\geq T 2$ (5). The aim of NAC is to down-stage the tumor before resection, inhibit micrometastasis, increase the RO resection rate and reduce the risk of recurrence and metastasis. Tumors which are not suitable for resection can be shrunk with NAC to become suitable for operation. Consequently, while survival rates increase with NAC, the radical resection rate and the risk of postoperative recurrence and metastasis decrease $(6,7)$.

Many studies have been conducted to determine the factors affecting prognosis in operable gastric cancer, and the TNM grading system is accepted as the most important independent prognostic factor by the American Joint Committee on Cancer (AJCC) (8). In addition, the presence of lymph node metastasis without serosal involvement, the extent of lymphatic spread, invasion depth, tumor macroscopic type, histological growth pattern, the presence of lymphovascular invasion (LVI), tumor region, grade, and resection type, and patient age have also been shown to have an effect on prognosis (9-11).

Although studies have shown that reaching pathological complete response ( $p C R$ ) with NAC provides a survival advantage in LAGC, there have been no studies investigating in which conditions there is an increase in PCR $(12,13)$. The $P C R$ rate with neoadjuvant treatment in gastric and gastroesophageal junction cancers varies between $15 \%$ and $30 \%$, and the chance of R0 resection has been reported to be $70-77 \%(14,15)$. There are also studies showing an increase in survival with a partial response even if pCR is not obtained (16). However, not all LAGCs benefit from NAC, and approximately $15 \%$ of pa- tients show tumor progression (17). While NAC provides an improvement in prognosis for patients with increasing $\mathrm{pCR}$ and the chance of RO resection, it may cause a delay in surgery and disease progression in the patient group who do not respond or have an insufficient response (13). The determination of the patient groups for which NAC is more effective will allow the selection of subgroups who will benefit from treatment and eliminate unwanted delays for other groups, thereby providing more benefit to the prognosis of patients.

The aim of this study was to investigate the tumor characteristics in gastric cancer that respond better to NAC.

\section{MATERIALS AND METHODS}

\section{Data collection}

The study included 38 patients who received NAC at Medipol University Hospital and then underwent surgery at Medipol University Hospital and Gaziosmanpasa Training and Research Hospital between January 2015 and April 2019, reviewed retrospectively.

Approval for this study was granted from Gaziosmanpasa Training and Research Hospital Ethics Committee for Clinical Studies (Date: 28.05.2020, No: 80). The study was performed in accordance with the Declaration of Helsinki.

The study inclusion criteria were as follows: 1) Histopathological diagnosis of adenocarcinoma, and 2) A clinical LAGC diagnosis ( $\geq T 2$, Nany). Patients were excluded from the study if they had distant metastasis, and other exclusion criteria were as follows: 1) Non adenocarcinoma histology, 2) Emergency or palliative resection during treatment, 3) The patient refused to complete the neoadjuvant treatment, 4) There were contraindications for NAC and surgery, 5) A history of gastric surgery.

Evaluation was made of 38 patients diagnosed with LAGC after the exclusion of 31 patients following further tests; 9 were determined to have metastasis, 10 with bleeding, seven with partial obstruction, and five applied to have emergency surgery because of perforation. No patient abandoned treatment. All patients underwent preoperative metastasis scanning, and before NAC, evaluation with gastroscopy and abdominal computed tomography (CT). All the patients were diagnosed with adenocarcinoma, and in seven patients there was signet ring cell differentiation. 
The majority of patients received chemotherapy with the FOLT protocol and the FOLFOX regimen was applied to only three patients. The data flow chart is shown in Figure 1.

Data were retrieved from the medical records of each patient in respect of medical history, age, sex, chemotherapy regimen of NAC, surgical method, and pathology results (e.g. histological type, tumor size, histological grade, perineural invasion (PNI), LVI and laboratory data.) The tumor size ( $T$ stage), lymph node status ( $\mathrm{N}$ stage), presence of metastasis ( $M$ stage) and the American Joint Committee on Cancer (AJCC) stage for each patient were obtained from the cancer registry data (5). Tumor size was assessed in three groups as $<4.5 \mathrm{~cm}, 4.5-8 \mathrm{~cm}$ and $>8 \mathrm{~cm}$ (18).

In histological evaluation, the data obtained from all patients were included in the statistics and histological type, grade, presence of perineural invasion, presence of lymphovascular invasion and human epidermal growth factor receptor 2 (HER 2) status were included in the evaluation. Both the WHO classification and the Lauren classification were used for histological evaluation. In the Lauren classification, it was evaluated in 3 groups as diffuse intestinal and mixed type, as it was made in 1965 and is still ongoing. According to the WHO classification, it was

Eligibility criteria:

1. Histopathological diagnosis of adenocarcinoma,

2. A clinical LAGC diagnosis ( $\geq \mathrm{T} 2$, Nany)

Exclusion criteria:

1. Patients with distant metastases

2. Emergency or palliative resection during treatment,

3. The patient refused to complete the neoadjuvant treatment,

4. There were contraindications for NAC and surgery

5. A history of gastric surgery $\mathrm{n}=69$

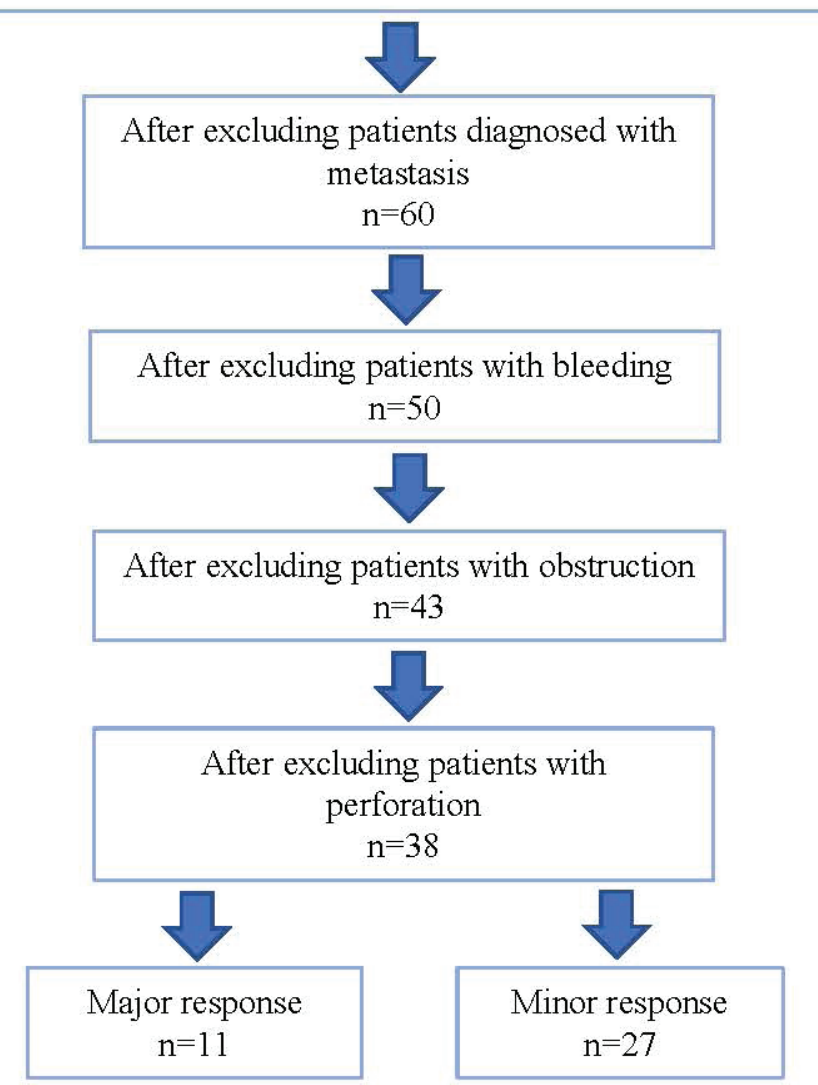

Figure 1: The data flow chart 
graded in 3 groups as well-differentiated, moderately differentiated and poorly differentiated $(19,20)$. In the HER 2 scoring, 0 was accepted as no reaction in tumor cells or incomplete reaction in $\leq 10 \%$ of tumor cells, 1 as paleness in $>10 \%$ of the tumor cells and incomplete membranous reaction that was difficult to differentiate, 2 as incomplete weak or moderate level membranous reaction in $>10 \%$ of the tumor cells or a complete strong membranous reaction in $\leq 10 \%$ of the tumor cells, and 3 as a uniform strong membranous reaction in $>10 \%$ of the tumor cells. Scores 0 and 1 were accepted as negative, Score 2 as suspected positive, and Score 3 as a positive reaction. Patients with Score 2 were then evaluated according to fluorescent in situ hybridization (FISH), and were included in the negative or positive group according to the results (21).

\section{Chemotherapy}

For neoadjuvant treatment, the patients were administered the FLOT regimen (docetaxel $\left(50 \mathrm{mg} / \mathrm{m}^{2}\right)$, oxaliplatin $\left(85 \mathrm{mg} / \mathrm{m}^{2}\right)$, and LV $\left(200 \mathrm{mg} / \mathrm{m}^{2}\right)$ with short-term infusional FU (2600 $\mathrm{mg} / \mathrm{m}^{2}$ as a 24 -hour infusion) or the FOLFOX regimen (oxaliplatin $85 \mathrm{mg} / \mathrm{m}^{2} \mathrm{IV}+$ leucovorin $400 \mathrm{mg} / \mathrm{m}^{2} \mathrm{IV}+$ fluorouracil $400 \mathrm{mg} / \mathrm{m}^{2}$ IV bolus + fluorouracil $\left.2400 \mathrm{mg} / \mathrm{m}^{2} \mathrm{IV}\right)(22,23)$.

\section{Surgery}

The surgical technique applied to all the patients was D2 lymphadenectomy with curative total gastrectomy. D2 lymph node dissection including the $1,2,3,4,5,6,7,8$ a, $9,11 p, 11 d$ and 12 were performed so that at least 15 lymph nodes were removed (24).

\section{Assessment of chemotherapy response}

Following retrospective collection of patient demographic data, such as age and gender, the radiological, gastroscopic, and histopathological findings before and after NAC were compared with the pathological response. In the histopathological examination, evaluations were made of tumor grade, differentiation, PNI, and LVI, and the presence of HER 2 and necrosis to determine which tumors with which characteristics benefited most from NAC.

The College of American Pathologists Tumor Regression Grading (CAP-TRG) system was used to evaluate the response to NAC. Classification in this system is defined as Grade 0: No viable cancer cells (complete response); Grade 1: Single cells or small groups of cancer cells (moderate response); Grade 2: Residual cancer cells with evident tumor regression but more than single cells or rare small groups of cancer cells (minimal response); Grade 3: Minimal or no tumor killed or extensive residual cancer (poor response) (25). The response to treatment in the histopathology samples according to the CAP-TRG system is shown in Figure 2.
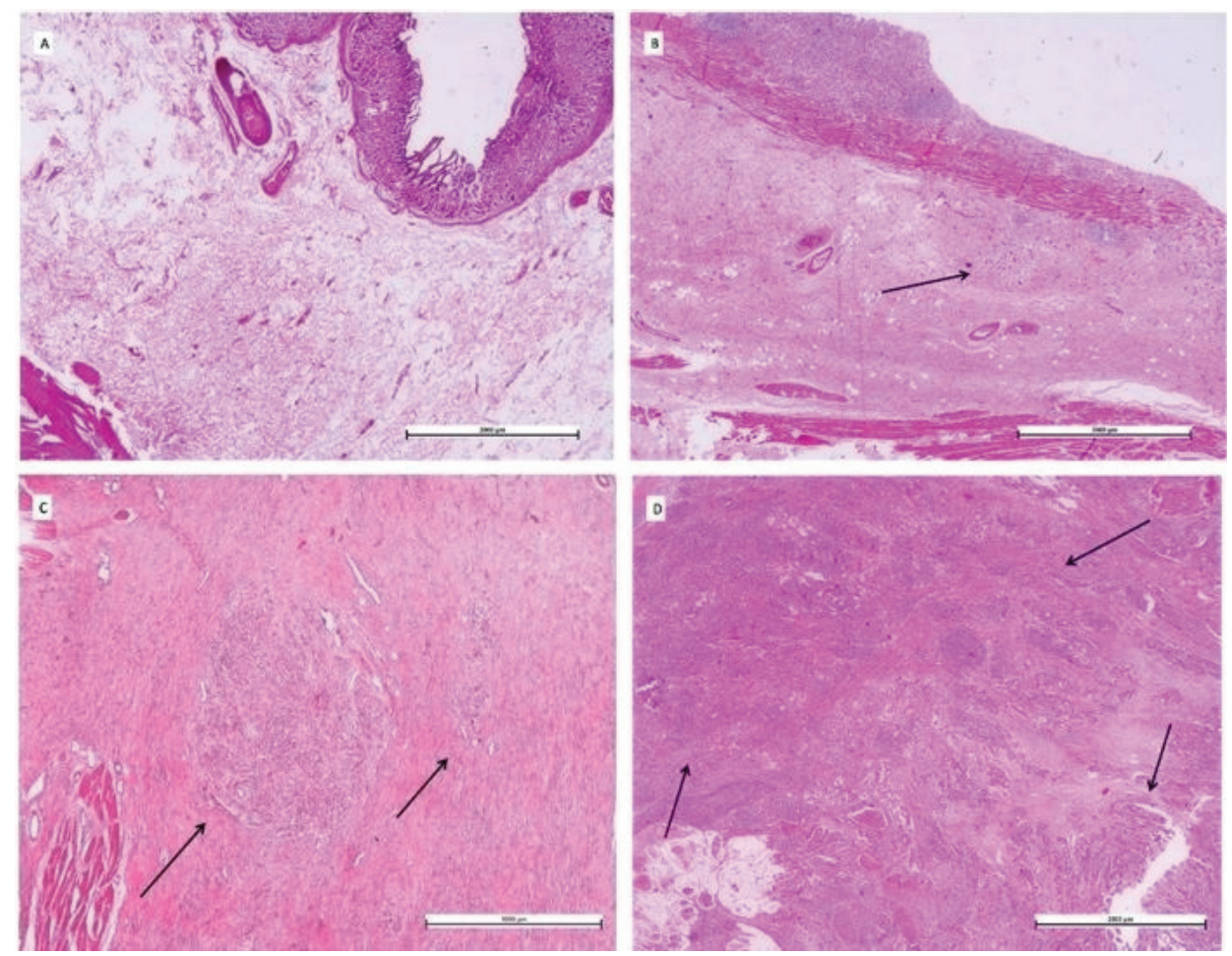

Figure 2: The response rates to asses neoadjuvant chemotherapy according to the College of American Pathologists Tumor Regression Grading (CAP-TRG) A) CAP-TRG Grade 0 (pCR), B) CAP-TRG Grade 1, C) CAP-TRG Grade 2, D) CAP-TRG Grade 3 (H\&E x 20). 
All subsequent analyses were made after separating the patients into major response (grades 0 and 1 ) and minor response (grades 2 and 3) (26).

From the hemoglobin level in the routine blood tests performed one week before NAC, the neutrophil-lymphocyte rate (NLR) was calculated as the ratio of absolute neutrophil count to absolute lymphocyte count, and the correlation of NLR to response to NAC was evaluated.

\section{Clinical outcomes}

Prognosis was analyzed with the disease-free survival rate (defined as the time elapsed between surgery with curative intent and reappearance of disease, either locally or distant in months) and the overall survival rate (defined as the time elapsed between surgery with curative intent and death due to disease in months).

\section{Follow-up}

In the first two years after surgery, patients were followed up regularly at three or four-month intervals and then every six months in the third year, and annually thereafter. During the follow-up visits, patients underwent physical examination, complete blood tests, chest radiography and CT or magnetic resonance imaging (MRI) as clinically indicated. Upper gastrointestinal endoscopy was used to verify locoregional recurrence.

\section{Statistical analysis}

All statistical analyses were performed using the SPSS software (version 21.0; SPSS Inc., Chicago, IL, USA). Conformity of continuous variables to normal distribution was assessed with the Shapiro Wilk test. Normally distributed parametric data were presented as mean \pm standard deviation (SD) values. In the comparison of variables showing normal distribution, according to the major and minor response groups, the Student's t-test was used and for those not showing normal distribution, the Mann Whitney U-test. The Chi-square test and Fisher's Exact test were applied in the analysis of categorical data. To determine variables with an effect on the groups, Logistic Regression Analysis was performed. The survival analysis was calculated using the Kaplan-Meier method, and the log-rank test was used for the univariate analysis. A value of $\mathrm{p}<0.05$ was accepted as statistically significant.

\section{RESULTS}

Evaluation was made of 38 patients diagnosed with LAGC. There was a PCR to chemotherapy in 2 (6\%) patients, Grade 1 in 9 (24\%) patients, Grade 2 in 13 (34\%), and Grade 3 in 14 (36\%). The relationships between the pathological response and the laboratory findings, demographic and histopathological data are shown in Table 1.

When the statistical results were examined, a significant relationship between the presence of $\mathrm{PNI}$ and a poor response to NAC in univariate analysis $(p=0.023)$ was observed. In logistic regression analysis, only the presence of PNI was found to be related to the absence of tumor regression (OR: 9.692;( Cl 1.074-87.437); $p=0.043$ ). A large proportion of patients with a major response were Her 2 negative, high grade and without LVI, but this was not statistically meaningful ( $p>0.05)$. No statistically significant relationship was seen between hemoglobin levels and NLR and pathological response $(p=0.625$ and $p=0.727$, respectively). In patients with $p C R$, there was no $\mathrm{PNI}$ and $\mathrm{LVI}$, and the tumor grade was high in these patients. There was regression in tumor size and the possibility of $\mathrm{R} 0$ resection was obtained in all patients. No relationship was determined between major response and overall survival (OS), disease-free survival (DFS), metastasis and recurrence $(p>0.05)$. The follow-up periods, DFS, OS, metastasis, and mortality rates are shown in Table 2. No metastasis or mortality was seen in the patients with pathological complete response. The multivariate analysis results are shown in Table 3. Overall survival according to histopathological response groups is summarized in Figure 3.

\section{DISCUSSION}

Significant changes have happened in oncological therapy in recent years, and are reported to improve prognosis, especially in local advanced stage tumors with neoadjuvant therapy (27). Neoadjuvant treatment of aggressive solid organ malignancies has many proven advantages. Early treatment of distant microscopic disease is provided with NAC, and shrinkage can occur in the tumor increasing resectability (28). There are publications in LAGC with NAC, there is an increase up to $30 \%$ in $\mathrm{PCR}$ and $\mathrm{R} 0$ resection up to $100 \%$, although the complete response rates are not high in most researches (16, $29,30)$. In this regard, it is important to determine which patients will be preferred by NAC. Factors affecting NAC response have been researched in our study for this purpose. Our study assessed in which patient group the pathological response was better, and $\mathrm{R} 0$ resection could be done in all patients after NAC even if it was not pCR.

Shrinkage of the tumor to obtain $\mathrm{RO}$ resection in patients diagnosed with LAGC has an effect on prognosis and facilitates surgery. In the MAGIC study, 503 patients diagnosed with $\geq T 2$ stomach, gastroesophageal junction, and distal esophagus adenocarcinoma were randomized into two groups. One group had surgery only and the patients in the other group were given NAC, then operated on, and were subsequently administered adjuvant chemotherapy. The results of that study showed that pCR was not obtained with NAC but the resected tumors were significantly smaller in size and less nodal metastasis was determined. Although $58 \%$ of the patients could 
Table 1: Summary of the demographic, histopathological and laboratory findings of the patients according to response

\begin{tabular}{|c|c|c|c|c|c|c|c|c|}
\hline \multirow{2}{*}{\multicolumn{2}{|c|}{ Age (year) }} & \multicolumn{2}{|c|}{$\begin{array}{c}\text { Major response } \\
n(11) \\
\text { mean } \pm S D\end{array}$} & \multicolumn{2}{|c|}{$\begin{array}{c}\text { Minor response } \\
n(27) \\
\text { mean } \pm S D\end{array}$} & \multicolumn{2}{|c|}{$\begin{array}{c}\text { Total } \\
\mathrm{n}(38) \\
\text { mean } \pm S D\end{array}$} & $p$ value \\
\hline & & \multicolumn{2}{|c|}{$62.41 \pm 10.54$} & \multicolumn{2}{|c|}{$58.52 \pm 11.84$} & \multicolumn{2}{|c|}{$59.65 \pm 11.48$} & $0.356^{a}$ \\
\hline \multicolumn{2}{|l|}{ NAC_If $\left(10^{9} / L\right)$} & \multicolumn{2}{|c|}{$2.39 \pm 1.28$} & \multicolumn{2}{|c|}{$1.88 \pm 0.68$} & \multicolumn{2}{|c|}{$2.03 \pm 0.91$} & $0.278^{a}$ \\
\hline \multicolumn{2}{|l|}{ NAC_nt $\left(10^{9} / \mathrm{L}\right)$} & \multicolumn{2}{|c|}{$4.68 \pm 2.63$} & \multicolumn{2}{|c|}{$5.04 \pm 2.42$} & \multicolumn{2}{|c|}{$4.94 \pm 2.46$} & $0.751^{a}$ \\
\hline \multicolumn{2}{|l|}{ NLR } & \multicolumn{2}{|c|}{$2.89 \pm 1.25$} & \multicolumn{2}{|c|}{$3.07 \pm 1.59$} & \multicolumn{2}{|c|}{$3.02 \pm 1.48$} & $0.727^{a}$ \\
\hline \multicolumn{2}{|l|}{$\mathrm{HB}(\mathrm{g} / \mathrm{dl})$} & \multicolumn{2}{|c|}{$12.37 \pm 2$} & \multicolumn{2}{|c|}{$12.03 \pm 1.89$} & \multicolumn{2}{|c|}{$12.13 \pm 1.90$} & $0.625^{\mathrm{b}}$ \\
\hline & & $\mathrm{n}$ & $\%$ & $n$ & $\%$ & $n$ & $\%$ & $p$ value \\
\hline Gender (\%) & & & & & & & & \\
\hline & Male & 10 & 90.9 & 21 & 77.8 & 31 & 81.6 & $0.648^{b}$ \\
\hline & Female & 1 & 9.1 & 6 & 22.2 & 7 & 18.4 & \\
\hline Tumor localizat & ion & & & & & & & \\
\hline & Proximal & 2 & 18.2 & 6 & 22.2 & 8 & 21.1 & $0.852^{c}$ \\
\hline & Distal & 6 & 54.5 & 12 & 44.4 & 18 & 47.4 & \\
\hline & EGJ & 3 & 27.3 & 9 & 33.3 & 12 & 31.6 & \\
\hline Tumor size $(\mathrm{cm})$ & & & & & & & & \\
\hline & $<4.5 \mathrm{CM}$ & 7 & 63.6 & 11 & 40.7 & 18 & 47.4 & $0.427^{c}$ \\
\hline & 4.5-8 CM & 3 & 27.3 & 13 & 48.1 & 16 & 42.1 & \\
\hline & $>8 \mathrm{CM}$ & 1 & 9.1 & 3 & 11.1 & 4 & 10.5 & \\
\hline Stage & & & & & & & & \\
\hline & Stage $2 a$ & 1 & 9.1 & 0 & 0 & 1 & 2.6 & $0.174^{c}$ \\
\hline & Stage $2 b$ & 0 & 0 & 4 & 14.8 & 4 & 10.5 & \\
\hline & Stage 3 & 8 & 72.7 & 21 & 77.8 & 29 & 76.3 & \\
\hline & Stage $4 a$ & 2 & 18.2 & 2 & 7.4 & 4 & 10.5 & \\
\hline Lauren classific & ation & & & & & & & \\
\hline & Intestinal & 3 & 27.3 & 9 & 33.3 & 12 & 31.6 & $0.644^{c}$ \\
\hline & Diffuse & 5 & 45.5 & 8 & 29.6 & 13 & 34.2 & \\
\hline & Mixed & 3 & 27.3 & 19 & 0.37 & 13 & 34.2 & \\
\hline Differentiation & & & & & & & & \\
\hline & Well-moderate & 4 & 36.4 & 9 & 33.3 & 13 & 34.2 & $1.00^{b}$ \\
\hline & Poorly & 7 & 63.6 & 18 & 66.7 & 25 & 65.8 & \\
\hline Grade & & & & & & & & \\
\hline & Low-moderate & 2 & 18.2 & 11 & 40.7 & 13 & 34.2 & $0.268^{b}$ \\
\hline & High & 9 & 81.8 & 16 & 59.3 & 25 & 65.8 & \\
\hline $\mathrm{PNI}$ & & & & & & & & \\
\hline & Absent & 9 & 0.9 & 13 & 48.1 & 22 & 59.5 & $0.028^{b *}$ \\
\hline & Present & 1 & 0.1 & 14 & 51.9 & 15 & 40.5 & \\
\hline LVI & & & & & & & & \\
\hline & Absent & 7 & 0.7 & 9 & 33.3 & 16 & 43.2 & $0.067^{b}$ \\
\hline & Present & 3 & 0.3 & 18 & 66.7 & 21 & 56.8 & \\
\hline HER 2 & & & & & & & & \\
\hline & Absent & 10 & 90.9 & 20 & 0.87 & 30 & 88.2 & $1.00^{b}$ \\
\hline & Present & 1 & 9.1 & 3 & 0.13 & 4 & 11.8 & \\
\hline
\end{tabular}

a: Mann Whitney U test, $b$ : Fisher Exact test, $c$ : Chi-Square test, *: refers to the higher ratio $(p<0.05)$.

SD: Standard deviation, NAC_If: One week before NAC the lymphocyte ratio. NAC_nt: One week before NAC the neutrophil ratio,

NLR: neutrophil to lymphocyte ratio, HB: hemoglobin, EGJ: esophagogastric junction, HER 2: Human epidermal growth factor receptor-2,

PNI: perineural invasion, LVI: lymphovascular invasion 
Table 2: Follow up times of the patients, disease free survival (DFS), mean survival (OS) and findings of metastasis and death

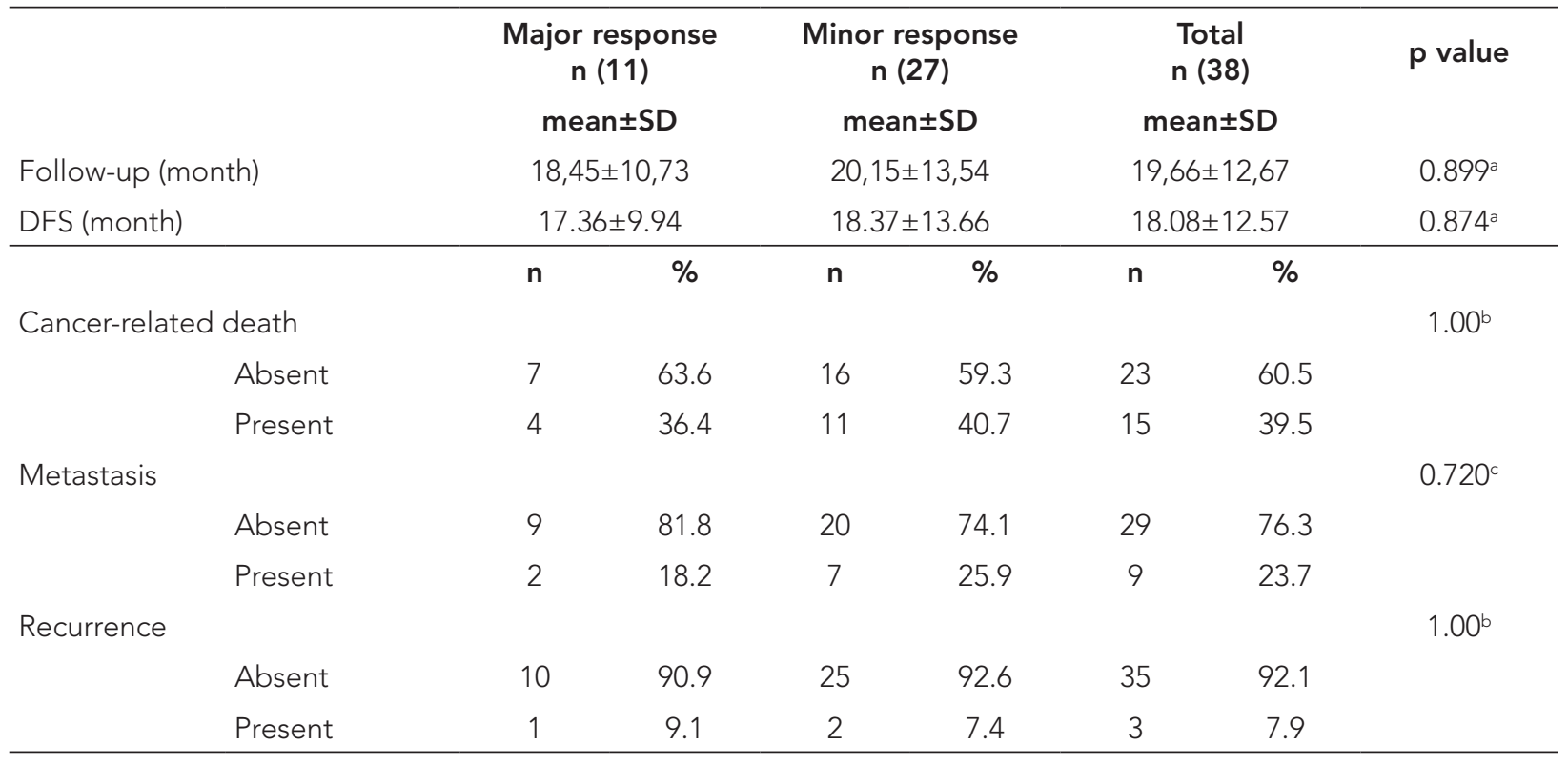

a: Mann Whitney U test, b: Fisher Exact test, c: Chi-Square test, DFS: Disease free survival

Table 3: Multivariate analysis

\begin{tabular}{lccccccc}
\hline & B & S.E. & Wald & Sig. & Exp (B) & \multicolumn{2}{c}{ 95\% C.I.for EXP(B) } \\
& & & & & & Lower Upper \\
NLR-categorical (>2.06) & 0.142 & 0.837 & 0.029 & 0.866 & 1.152 & 0.224 & 5.939 \\
PNI & 1.659 & 1.206 & 1.891 & 0.169 & 5.254 & 0.494 & 55.899 \\
LVI & 1.107 & 0.925 & 1.434 & 0.231 & 3.026 & 0.494 & 18.527 \\
Grade & -1.019 & 0.987 & 1.065 & 0.302 & 0.361 & 0.052 & 2.500 \\
Constant & 1.613 & 0.619 & 6.796 & 0.009 & 5.016 & \\
\hline
\end{tabular}

NLR: neutrophil to lymphocyte rate, PNI: perineural invasion, LVI: lymphovascular invasion, S.E.: standard error

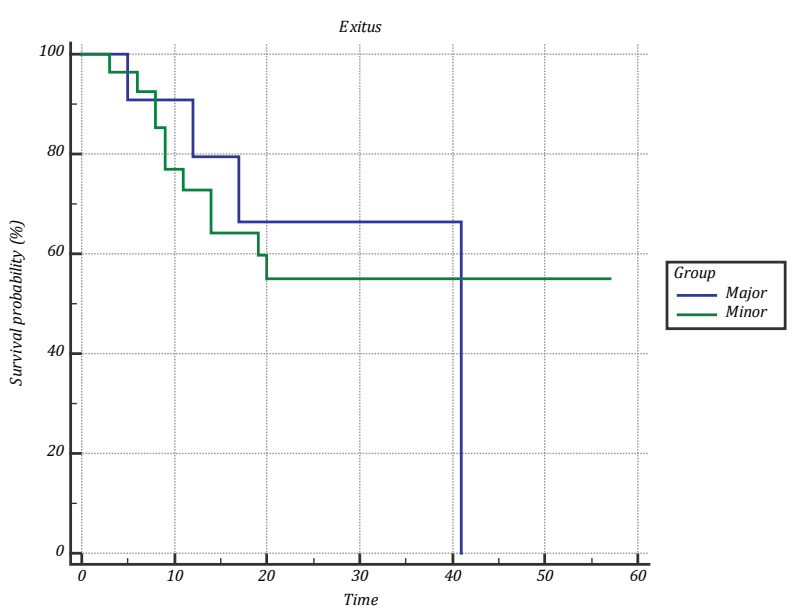

Figure 3: Overall survival according to histopathological response groups

Survival time does not differ between minor and major response groups $(p=0.876)$. not complete treatment in the postoperative period, OS and DFS were better in the group that received chemotherapy (31).

In a study by Ychou et al, 224 patients were randomized to surgery and NAC+adjuvant chemotherapy groups. The $\mathrm{RO}$ resection rate was seen to increase with NAC, and there was an improvement in OS and DFS rates (32).

Although many studies have shown an increase in survival and $\mathrm{RO}$ resection rates with neoadjuvant treatment in gastric cancer, as stated above, the factors affecting the increase in pathological response have not been extensively investigated. There are few studies in the literature on this subject. Li et al investigated the effect of HER 2, Ki67 and p53 proteins on NAC response and concluded that Ki67 was an independent determinant of NAC efficacy (33). In another study, HER 2 and p53 were found to be predictive factors of the response to neoadjuvant 
chemotherapy with the FOLFOX regimen (34). The histopathological factors predicting NAC response in LAGC were investigated in another study and the most important predictors affecting pathological response were reported to be tumor differentiation and tumor size (35). In 2017, Molina et al. examined histopathological parameters predicting NAC response in $L A G C$, and found that LVI, PNI, and high grade were associated with a poor response to treatment. No relationship was determined between NAC response and age, gender, inflammatory reaction in the tumor, and desmoplasia (26).

It is more difficult to obtain PCR in LAGC than in other solid organ tumors. The important question here is to determine which patients will have a better response to treatment. From the available data, it can be thought that there will be a better response to NAC in certain subgroups of gastric cancer.

The results of the current study showed a relationship between major pathological response and the absence of PNI. Furthermore, although not statistically significant, there was a better response to NAC in patients without LVI. In contrast to findings in literature, a better clinical response was observed in high grade tumors in the current study (26). However, no relationship was determined with age, gender, tumor localization, grade or size.

There are studies in the literature that have shown that of the hematological parameters, NLR is correlated with the long-term results in lung, colorectal, pancreas and stomach cancers and that an increased NLR is predictive of mortality. There are also studies that have shown an increase in lymphocyte count and an increase in anti-cancer activity associated with lymphocyte-mediated antibodies, and therefore claimed a potential increase in pCR $(36,37)$. However, the effect of NLR on pathological response has only been evaluated in one study. In that study of breast cancer patients receiving neoadjuvant chemotherapy, an increase in PCR when NLR was $<2.06$ (38-40) was determined.

When starting the current study, it was predicted that in addition to hemoglobin level and histopathological features such as PNI, LVI, grade and differentiation, NLR, as an inflammatory indicator, would be a factor affecting NAC response, but no relationship was determined between NLR and pathological response. The lymphocyte count was higher in the patient group showing a major response, but this was not reflected in the NLR. Predictive importance of NLR could not be determined in this study. Nevertheless, it could be predictive of NAC response in stomach cancer and in other malignancies such as breast cancer and lung cancer, and there can be considered to be a need for re-evaluation in further studies with larger patient numbers.
There were some limitations to this study, primarily that the endpoint was limited to PCR. The follow-up periods of the patients, OS and DFS were added to the study but long-term clinical results were not evaluated. As a limited number of patients were included in this study there is a need for further more extensive studies to reach significant results. The same chemotherapy regime wasn't applied to all of the patients. Although this did not affect the results, it can be assessed as a limitation. It is thought that with more robust evidence similar results will be obtained and should be supported with studies that will determine the parameters predicting NAC response.

In conclusion, the results of this study demonstrated that $\mathrm{PNI}$ is a parameter predicting response to chemotherapy in LAGC patients receiving NAC. In the clinical evaluation, the absence of LVI and high grade were correlated with good response. Given the fact that an increased lymphocyte count stimulates the immune response, and it has not been previously investigated as a factor with predictive value in gastric cancer, NLR was investigated as it can be easily calculated from routine blood tests in all patients at no extra cost, but it was not found to be statistically significant. However, further studies with a higher number of patients are needed for PNI and other parameters to be used in clinical practice.

Ethics Committee Approval: This study was approved by the Clinical Research Ethical Committee of the Istanbul Gaziosmanpasa Training and Research Hospital. (Date: 28.05.2020, No:80)

Peer Review: Externally peer-reviewed.

Author Contributions: Conception/Design of Study- E.Y.; Data Acquisition- I.Y., B.U.Y., S.G.A.; Data Analysis/InterpretationE.Y., S.B., A.M.E.; Drafting Manuscript- E.Y.; Critical Revision of Manuscript- E.Y., A.M.E., S.B., A.B.; Approval and Accountability- E.Y., S.B.,S.G.A., A.M.E., I.Y., P.Ö.G., B.U.Y., A.B., M.Ö.

Conflict of Interest: Authors declared no conflict of interest

Financial Disclosure: Authors declared no financial support.

\section{REFERENCES}

1. Bray F, Ferlay J, Soerjomataram I, Siegel RL, Torre LA, Jemal A. Global cancer statistics 2018: GLOBOCAN estimates of incidence and mortality worldwide for 36 cancers in 185 countries. CA Cancer J Clin 2018;68(6):394-424. [CrossRef]

2. Kikuchi S, Katada N, Sakuramoto S, Kobayashi N, Shimao H, Watanabe $M$, et al. Survival after surgical treatment of early gastric cancer: surgical techniques and long-term survival. Langenbecks Arch Surg 2004;389(2):69-74. [CrossRef]

3. Lu J, Huang CM, Zheng CH, Li P, Xie JW, Wang JB, et al. Consideration of tumor size improves the accuracy of TNM predictions in patients with gastric cancer after curative gastrectomy. Surg Oncol 2013;22(3):167-71. [CrossRef]

4. Gee DW, Rattner DW. Management of gastroesophageal tumors. Oncologist 2007;12(2):175-85. [CrossRef] 
5. Ajani JA, D'Amico TA, Almhanna K, Bentrem DJ, Chao J, Das P, et al. Gastric Cancer, Version 3.2016, NCCN Clinical Practice Guidelines in Oncology. J Natl Compr Canc Netw 2016;14(10):1286-312. [CrossRef]

6. Stewart C, Chao J, Chen YJ, Lin J, Sullivan MJ, Melstrom $L$, et al. Multimodality management of locally advanced gastric cancer-the timing and extent of surgery. Transl Gastroenterol Hepatol 2019;4:42. [CrossRef]

7. Wang XZ, Zeng ZY, Ye X, Sun J, Zhang ZM, Kang WM. Interpretation of the development of neoadjuvant therapy for gastric cancer based on the vicissitudes of the NCCN guidelines. World J Gastrointest Oncol 2020;12(1):37-53. [CrossRef]

8. Cao LL, Lu J, Li P, Xie JW, Wang JB, Lin JX, et al. Evaluation of the Eighth Edition of the American Joint Committee on Cancer TNM Staging System for Gastric Cancer: An Analysis of 7371 Patients in the SEER Database. Gastroenterol Res Pract 2019;2019:6294382. [CrossRef]

9. Yamamura Y, Nakajima T, Ohta K, Nashimoto A, Arai K, Hiratsuka $M$, et al. Determining prognostic factors for gastric cancer using the regression tree method. Gastric Cancer 2002;5(4):201-7. [CrossRef]

10. Yokota T, Ishiyama S, Saito T, Teshima S, Narushima Y, Murata $\mathrm{K}$, et al. Lymph node metastasis as a significant prognostic factor in gastric cancer: a multiple logistic regression analysis. Scand J Gastroenterol 2004;39(4):380-4. [CrossRef]

11. Bu Z, Zheng Z, Li Z, Zhang L, Wu A, Wu X, et al. Lymphatic vascular invasion is an independent correlated factor for lymph node metastasis and the prognosis of resectable T2 gastric cancer patients. Tumour Biol 2013;34(2):1005-12. [CrossRef]

12. Li Z, Shan F, Wang Y, Zhang Y, Zhang L, Li S, et al. Correlation of pathological complete response with survival after neoadjuvant chemotherapy in gastric or gastroesophageal junction cancer treated with radical surgery: A metaanalysis. PLoS One. 2018;13(1):e0189294. [CrossRef]

13. Cho H, Nakamura J, Asaumi Y, Yabusaki H, Sakon M, Takasu $\mathrm{N}$, et al. Long-term survival outcomes of advanced gastric cancer patients who achieved a pathological complete response with neoadjuvant chemotherapy: a systematic review of the literature. Ann Surg Oncol 2015;22(3):787-92. [CrossRef]

14. Ajani JA, Winter K, Okawara GS, Donohue JH, Pisters PW, Crane $\mathrm{CH}$, et al. Phase II trial of preoperative chemoradiation in patients with localized gastric adenocarcinoma (RTOG 9904): quality of combined modality therapy and pathologic response. J Clin Oncol 2006;24(24):3953-8. [CrossRef]

15. Ajani JA, Mansfield PF, Janjan N, Morris J, Pisters PW, Lynch PM, et al. Multi-institutional trial of preoperative chemoradiotherapy in patients with potentially resectable gastric carcinoma. J Clin Oncol 2004;22(14):2774-80. [CrossRef]

16. Kurokawa $Y$, Shibata $T$, Sasako M, Sano T, Tsuburaya A, Iwasaki $Y$, et al. Validity of response assessment criteria in neoadjuvant chemotherapy for gastric cancer (JCOG0507-A). Gastric Cancer 2014;17(3):514-21. [CrossRef]

17. Valenti V, Hernandez-Lizoain JL, Beorlegui MC, DiazGonzalez JA, Regueira FM, Rodriguez JJ, et al. Morbidity, mortality, and pathological response in patients with gastric cancer preoperatively treated with chemotherapy or chemoradiotherapy. J Surg Oncol 2011;104(2):124-9. [CrossRef]
18. Zhu Y, Sun $Y$, Hu S, Jiang $Y$, Yue J, Xue X, et al. Comparison of five tumor regression grading systems for gastric adenocarcinoma after neoadjuvant chemotherapy: a retrospective study of 192 cases from National Cancer Center in China. BMC Gastroenterol 2017;17(1):41. [CrossRef]

19. Lauren P. The Two Histological Main Types of Gastric Carcinoma: Diffuse and So-Called Intestinal-Type Carcinoma. An Attempt at a Histo-Clinical Classification. Acta Pathol Microbiol Scand 1965;64:31-49. [CrossRef]

20. Kushima R, Lauwers GY, Rugge M. Gastric Dysplasia. In: WHO Classification of Tumours: Digestive Systemic Tumours, 5th, WHO Classification of Tumours Editorial Board (Ed), International Agency for Research on Cancer, Lyon 2019. p.71

21. Bartley $A N$, Washington $M K$, Ventura $C B$, Ismaila $N$, Colasacco C, Benson AB, 3rd, et al. HER2 testing and clinical decision making in gastroesophageal adenocarcinoma: Guideline From the College of American Pathologists, American Society for Clinical Pathology, and American Society of Clinical Oncology. Arch Pathol Lab Med 2016;140(12):1345-63. [CrossRef]

22. Al-Batran SE, Hofheinz RD, Pauligk C, Kopp HG, Haag $G M$, Luley $K B$, et al. Histopathological regression after neoadjuvant docetaxel, oxaliplatin, fluorouracil, and leucovorin versus epirubicin, cisplatin, and fluorouracil or capecitabine in patients with resectable gastric or gastrooesophageal junction adenocarcinoma (FLOT4-AIO): results from the phase 2 part of a multicentre, open-label, randomised phase 2/3 trial. Lancet Oncol 2016;17(12):1697708. [CrossRef]

23. Bang YJ, Kim YW, Yang HK, Chung HC, Park YK, Lee KH, et al. Adjuvant capecitabine and oxaliplatin for gastric cancer after D2 gastrectomy (CLASSIC): a phase 3 open-label, randomised controlled trial. Lancet 2012;379(9813):315-21. [CrossRef]

24. Japanese Gastric Cancer Association. Japanese gastric cancer treatment guidelines 2018 (5th edition). Gastric Cancer 2021;24(1):1-21. [CrossRef]

25. Shi C, Berlin J, Branton PA, Burgart LJ, Carter DK, Compton CC, et al. Protocol for the examination of specimens from patients with carcinoma of the stomach. In: Cancer Protocol Templates. Northfield, IL: College of American Pathologists; 2017. (Available from: URL: http://www.cap.org)

26. Sanchez de Molina ML, Diaz Del Arco C, Vorwald P, Garcia-Olmo D, Estrada L, Fernandez-Acenero MJ. Histopathological factors predicting response to neoadjuvant therapy in gastric carcinoma. Clin Transl Oncol 2018;20(2):253-7. [CrossRef]

27. Russell MC. Comparison of neoadjuvant versus a surgery first approach for gastric and esophagogastric cancer. J Surg Oncol 2016;114(3):296-303. [CrossRef]

28. Ajani JA, Mansfield PF, Lynch PM, Pisters PW, Feig B, Dumas $P$, et al. Enhanced staging and all chemotherapy preoperatively in patients with potentially resectable gastric carcinoma. J Clin Oncol 1999;17(8):2403-11. [CrossRef]

29. Brenner B, Shah MA, Karpeh MS, Gonen M, Brennan MF, Coit DG, et al. A phase II trial of neoadjuvant cisplatinfluorouracil followed by postoperative intraperitoneal floxuridine-leucovorin in patients with locally advanced gastric cancer. Ann Oncol 2006;17(9):1404-11. [CrossRef] 
30. Koh YW, Park YS, Ryu MH, Ryoo BY, Park HJ, Yook JH, et al. Postoperative nodal status and diffuse-type histology are independent prognostic factors in resectable advanced gastric carcinomas after preoperative chemotherapy. Am J Surg Pathol 2013;37(7):1022-9. [CrossRef]

31. Cunningham D, Allum WH, Stenning SP, Thompson JN, Van de Velde CJ, Nicolson M, et al. Perioperative chemotherapy versus surgery alone for resectable gastroesophageal cancer. N Engl J Med 2006;355(1):11-20. [CrossRef]

32. Ychou M, Boige V, Pignon JP, Conroy T, Bouche $O$, Lebreton $\mathrm{G}$, et al. Perioperative chemotherapy compared with surgery alone for resectable gastroesophageal adenocarcinoma: an FNCLCC and FFCD multicenter phase III trial. J Clin Oncol 2011;29(13):1715-21. [CrossRef]

33. Li S, Li J, Liu Z, Zhang Z, Zhang W, Yang H, et al. [Predictive value of $\mathrm{P} 53, \mathrm{Ki}-67, \mathrm{HER} 2$ protein detection in neoadjuvant chemotherapy for adenocarcinoma of gastroesophageal junction). Zhonghua Wei Chang Wai Ke Za Zhi 2015;18(9):901-4.

34. Qu JJ, Shi YR, Hao FY. [Clinical study of the predictors to neoadjuvant chemotherapy in patients with advanced gastric cancer). Zhonghua Wei Chang Wai Ke Za Zhi 2013;16(3):276-80.

35. Wang LB, Teng RY, Jiang ZN, Hu WX, Dong MJ, Yuan XM, et al. Clinicopathologic variables predicting tumor response to neoadjuvant chemotherapy in patients with locally advanced gastric cancer. J Surg Oncol 2012;105(3):293-6. [CrossRef]
36. Shivakumar L, Ansell S. Targeting B-lymphocyte stimulator/ B-cell activating factor and a proliferation-inducing ligand in hematologic malignancies. Clin Lymphoma Myeloma 2006;7(2):106-8. [CrossRef]

37. Yao Y, Yuan D, Liu H, GuX, Song Y. Pretreatment neutrophil to lymphocyte ratio is associated with response to therapy and prognosis of advanced non-small cell lung cancer patients treated with first-line platinum-based chemotherapy. Cancer Immunol Immunother 2013;62(3):471-9. [CrossRef]

38. Kishi Y, Kopetz S, Chun YS, Palavecino M, Abdalla EK, Vauthey JN. Blood neutrophil-to-lymphocyte ratio predicts survival in patients with colorectal liver metastases treated with systemic chemotherapy. Ann Surg Oncol 2009;16(3):614-22. [CrossRef]

39. Aizawa M, Gotohda N, Takahashi S, Konishi M, Kinoshita T. Predictive value of baseline neutrophil/lymphocyte ratio for T4 disease in wall-penetrating gastric cancer. World J Surg 2011;35(12):2717-22. [CrossRef]

40. Chen Y, Chen K, Xiao X, Nie Y, Qu S, Gong C, et al. Pretreatment neutrophil-to-lymphocyte ratio is correlated with response to neoadjuvant chemotherapy as an independent prognostic indicator in breast cancer patients: a retrospective study. BMC Cancer 2016;16:320. [CrossRef] 